\title{
Libya, the United States and Russia in the Never-Ending Game of Checkers
}

\author{
Andrey V. Chuprygin, Larisa A. Chuprygina, \\ Valery A. Matrosov
}

\author{
Andrey V. Chuprygin \\ National Research University-Higher School of Economics, Moscow, Russia \\ Faculty of World Economy and International Affairs \\ School of Asian Studies \\ Senior Lecturer \\ SPIN RSCI: $3520-0398$ \\ ORCID: 0000-0002-2254-7707 \\ ResearcherID: J-8706-2015 \\ Scopus AuthorID: 57212673466 \\ E-mail: achuprygin@hse.ru \\ Address: Office B-310, 21/4, Bldg.5 Staraya Basmannaya Str., Moscow 105066, Russia \\ Larisa A. Chuprygina \\ National Research University-Higher School of Economics, Moscow, Russia \\ Faculty of World Economy and International Affairs \\ School of Asian Studies \\ Senior Lecturer \\ SPIN RSCI: 8636-0015 \\ ORCID: 0000-0003-4783-6211 \\ ResearcherID: I-4184-2015 \\ Scopus AuthorID: 57212672861 \\ E-mail: Lchuprygina@hse.ru \\ Address: Office B-310, 21/4, Bldg.5 Staraya Basmannaya Str., Moscow 105066, Russia \\ Valery A. Matrosov \\ National Research University-Higher School of Economics, Moscow, Russia \\ Faculty of World Economy and International Affairs \\ School of Asian Studies \\ Lecturer
}


SPIN RSCI: 9562-8350

ORCID: 0000-0002-3316-0444

ResearcherID: B-6255-2019

E-mail:vmatrosov@hse.ru

Address: Office B-310, 21/4, Bldg.5 Staraya Basmannaya Str., Moscow 105066, Russia

This paper is part of the Project "The Mediterranean Region in the Context of Political

Process in the Middle East and North Africa" carried out with grant support from the NRUHSE Faculty of World Economy and International Affairs.

DOI: $10.31278 / 1810-6374-2021-19-3-50-63$

\section{Abstract}

During the short period of Donald Trump's presidency, U.S. foreign policy underwent significant changes. The visible decline in the activity in the southern and south-eastern Mediterranean in previous years gave way to Washington's increased diplomatic activity in the settlement process. Although the lion's share of U.S. foreign policy in the MENA region was aimed at resolving the Arab-Israel confrontation, it did not ignore local conflicts such as the Libyan crisis, which at first glance has little to do with the main goals of the U.S. policy the region.

Washington's participation in the August 2020 negotiation process made it, along with Moscow and Ankara, a guarantor of a truce between the two main camps: the "Western bloc" represented by the internationally recognized Government of National Accord (GNA) led by Fayez al-Sarraj, and the "Eastern bloc" represented by Commander-in-Chief of the Libyan National Army (LNA) Khalifa Haftar. In many ways, the U.S. efforts facilitated the election of Libya's interim government, which came as a peculiar result of Trump's regional policy and charted a new vector to developments in Libya.

Even though Russia did not get involved in settling the Libyan crisis immediately after the civil war broke out in the country in 2011, it has strengthened its position on the Libyan track as a mediator in negotiations while formally remaining barely interested in supporting a particular Libyan side.

In this regard, two questions arise: How will the change in the U.S. policy in the region affect Moscow's position on the Libyan issue and on the developments in the eastern Mediterranean in general? And what new threats and challenges will Russia face in the event of a radical change in the United States' role in the region? 
Keywords: Libya, Trump's policy in the MENA region, Russia in the Mediterranean, Turkey in North Africa.

\section{THE LIBYAN CRISIS AND EXTERNAL INVOLVEMENT}

External involvement has had a significant impact on the course of events in Libya since the very beginning of the conflict in the spring of 2011. The infamous NATO bombing that destroyed the country's basic infrastructure, the support of various Islamist groups from the Gulf states, and the direct intervention by the UAE and Egypt on the side of the LNA laid the foundations of a "bloc" system, within which almost all significant external actors, in one way or another, officially or unofficially, have been supporting the political forces in the west or east of Libya.

The political split in Libya that deepened at the end of 2015 and the beginning of 2016, and the Skhirat agreement (also known as the Libyan Political Agreement signed in December 2015) created a specific configuration of political forces, which remained relevant until 2020 (Chuprygin et al., 2019). In the west of the country, in Tripoli, the UNrecognized Government of National Accord (NTC) headed by Fayez al-Sarraj was established, although not immediately, and not without reservations. In Cyrenaica, three state structures came into the political arena: the House of Representatives (the parliament that fled from Tripoli) headed by Speaker Aguila Saleh; the Government which chose Al-Bayda as its seat; and the Libyan National Army, whose Commanderin-Chief, Field Marshal (since 2016) Khalifa Haftar, quickly became a more significant figure for external actors than Saleh himself.

The Libyan conflict involves various groups of the population and elites, whose identity and legitimacy are associated with a variety of political, religious, and cultural models. Such a multifaceted nature of the conflict created a host of reasons, by appealing to which external actors have returned to the Libyan arena with renewed vigor. For most of them, participation in the conflict is an excellent opportunity to sort out their contradictions. Logically, it would be convenient to consider external actors in pairs-from the most obvious and active (Saudi 
Arabia and Qatar, France and Turkey) to the less active ones (Morocco and Algeria, Russia and the United States). However, there is also Italy as an active player, which is pursuing its own type of engagement, quite different from that of the others.

Russia and the United States are perhaps the least apparent pair in this mosaic. Firstly, because both these countries did not immediately get involved in the Libyan debacle, later did it sporadically and not quite systematically (Washington distanced itself so fast that considering it an active party would be misleading at best). Secondly, the role of each of these parties is ambiguous. Thirdly, the search for a solution to the current situation is not an end goal either for Moscow or Washington but rather a means to strengthen their positions as crucial parties to decision-making in the southern Mediterranean (which, however, is typical of most other external participants in the confrontation).

Unsystematic involvement in the conflict can largely be explained by the lack of a clear, historically determined position on Libya in both Russia and the United States. Although the anti-monarchist 1969 revolution was warmly welcomed by Moscow and with undisguised hostility by Washington, especially when shortly after the coup Muammar al-Gaddafi nationalized corporations and closed foreign military bases, the "colonel himself did not, contrary to popular opinion, become either a close friend of Moscow or enemy number one for Washington" (Breslauer, 1990, p. 27). For all its apparent anti-Western character, al-Gaddafi's foreign policy was an attempt to balance between the two poles, and by the time the regime was overthrown in 2011 neither side seemed to have developed a clear position on Libya. This ambiguity gave certain political pundits "reasons" to advocate the "need for NATO's intervention" under the guise of enforcing democracy and protecting the people, claiming the "divine right" to interfere with the lives of others.

Furthermore, involvement in several conflicts precipitated by the Arab Spring seemed more promising for Russia and the United States. For example, both states got extensively involved in the Syria crisis, and its outcome was much more important for their strategic interests than that of the Libyan confrontation. 
Staking on one side in the Libyan conflict presented specific difficulties. The current configuration of forces developed in 20152016 outside of the White House's or the Kremlin's initiatives, leaving both Russia and America with a very peculiar choice (Trenin, 2016).

For the United States, support for Khalifa Haftar would have been logical: he had lived in America for many years under the CIA's direct supervision, and his return to Libya was likely driven not only by personal ambitions (BBC, 2019). It looked that he was also motivated by active support from the outside. On the other hand, as the UN and most of the European states sided with the GNA in Tripoli following the Skhirat agreement, it was more logical to rely on the compromise figure of al-Sarraj, especially since Haftar behaved more and more independently, obviously irritating the White House.

As for Russia, it did not bet squarely on any of the competing parties. At the official level, the Foreign Ministry took a neutral position, conducting a dialogue with all sides to the conflict. Representatives of the elites in both Tobruk and Tripoli repeatedly visited Moscow, which made Russia's position unique: unlike NATO countries which spotted their reputation by participating in the escalation of the conflict, the Kremlin could earnestly claim the role of the primary mediator (Mezran and Varvelli, 2017, pp. 73-74). However, the lack of explicit rapport from both sides hindered the establishment of a strong, trustful relationship between them and Moscow. Some also argue that the rapport could be hampered by Moscow's "Wagner roadshow." Our position is that playing both sides, as the French experience shows, provides a great deal of latitude from the Libyan actors to their foreign parties to negotiations.

The ambivalence of Moscow's and Washington's positions, where the former displayed adherence to international rules and the latter showed indecision, hampered their participation in the Libyan developments. Nevertheless, the need to maintain the status of world powers unavoidably pushed both countries to involvement in the North African arena sooner or later, and Moscow was the first to show the initiative.

Russia made efforts to participate in the conflict as a mediator since 2016. In January 2017, when the aircraft carrier Admiral Kuznetsov 
anchored near Tobruk, and Haftar was personally invited to hold a video conference with Russian Defense Minister Sergei Shoigu, Moscow's interference in Libya's affairs became obvious (Mezran and Varvelli, 2017, p. 81). Until 2020, the United States had refrained from a visible response. However, after Turkey had intervened in the conflict and the Russian Wagner PMC's participation in the battle of Tripoli had become obvious, Washington's public response changed dramatically, especially after Haftar was pushed back to the old positions.

Russia's latest effort was made in the winter of 2020 during the Berlin Conference, which formulated basic principles of a truce between the warring parties. However, although the conference made much noise in the mass media, it had a minimal effect: Haftar continued to advance to Tripoli (Belenkaya, 2020). After the defeat of the marshal's offensive, the conflict entered a new phase. Aguila Saleh took the initiative to act on behalf of the "Eastern bloc" on the home stage and the United States came as a guarantor of the future truce in the external arena.

Russia's shrinking participation can largely be explained by Moscow's uncertainty mentioned above, which undermined the local players' confidence in it. NTC Deputy Prime Minister Ahmed Maiteeq's visit to Russia in June 2020 demonstrated a low level of contact with Tripoli: Maiteeq subsequently expressed severe doubts about Moscow's desire to maintain relations with the NTC. Aguila Saleh, whose peace initiatives were coordinated with the Kremlin in the spring of 2020, stopped mentioning Moscow as a guarantor in his calls for a truce at the end of the summer, which should have been taken as a serious signal to Moscow (Belenkaya, 2020).

After the Berlin Conference, Moscow did not take any significant steps to maintain contact with the parties and did not offer any essentially new approaches. However, the reorientation of the Libyan elites to the United States came not only as a result of Russian foreign policy failures but also due the transformation of the U.S. Libya policy.

\section{TRUMP'S MIDDLE EASTERN POLICY}

When the Trump administration took the reins of power in the United States in 2017, it inherited Barack Obama's uncertain political course, 
which was basically reduced to general statements about the protection of U.S. national security interests and human values around the world, as well as to specific measures such as the introduction of sanctions against several individuals and companies (Durret, 2017, pp. 11-13). Also, sporadic actions were taken against the ISIS forces, including the bombing of camps and the elimination of individual representatives of the terrorist organization, etc. During the first year and a half of Trump's presidential term there were hardly any changes in this policy (except, of course, for the ratification of old sanctions and the introduction of new ones).

The situation began to change in the spring of 2018 with the appointment of Stephanie Williams as U.S. Chargé d'Affaires in Libya. Having extensive experience in diplomatic service, including in crisis situations (in Bahrain during the social upheavals of 2011, and later in Iraq), Williams began to probe for strengthening Washington's position in the region. Russia's growing influence was beginning to worry the White House in earnest, and the United States' rising activism in Libya was aimed, of course, at asserting its influence in the region as a counteraction to Russia's efforts. That was the peak of Moscow's diplomatic activity in Syria: together with Turkey and Iran, Russia, in general terms, ensured the end of the long-term conflict and implemented further necessary political steps. The formation of this alliance could not but raise serious concerns in the White House as it could significantly reduce its ability to influence the entire eastern Mediterranean.

Already in June and July 2018, negotiations were organized with many participants in the conflict. Williams consistently conducted interviews with representatives of the NTC, municipalities in the west of the country, and tribal sheiks in the east. Direct contacts with the LNA and Khalifa Haftar were practically excluded, especially since the U.S. directly criticized his seizure of oil fields and demanded that they "return" under the NTC's control. However, even without this, the involvement of a large number of parties in the negotiations seemed more than representative, and already in July 2018 Stephanie Williams was invited to participate in the UN Support Mission in Libya 
(UNSMIL). In March 2020, when Ghassan Salame resigned as head of the Mission, Stephanie Williams had already served for ten months, making active efforts to reconcile the warring forces in the country.

The year 2020 was the most favorable moment for the U.S. to intensify its policy in the country: the coronavirus threatened a humanitarian crisis, Haftar's attack on Tripoli choked with the deployment of Turkish troops into the capital, and the fact that the arms embargo, which all Western countries formally supported, "turned into a joke" (EG24News, 2020). All this required increased control. Attempts at settling relations between Tripoli and Tobruk revealed Moscow's distrust which we mentioned above. As a result, Washington, which sought to reduce Russia's positions in the region, hastened to fill the gap, claiming that the situation threatened to "involve several of the U.S partner countries in the confrontation, in parallel with the growth of Russia's influence" (Blanchard, 2020, p. 21).

In November 2020, Stephanie Williams and her team launched the Libyan Political Dialogue Forum (LPDF), a conference that brought together seventy-five delegates from different parts of the country. The principle of selection of the Forum participants is still not entirely clear: most agree that the delegates were chosen by the Libyan public, but some media claim that the NTC appointed 26 people while Williams personally chose the remaining 49, and when recruiting the Forum, she was apparently inclined to cooperate with Islamists (Al-Marsad, 2020). Such information is hardly ultimate truth, but the fact that Williams forced the selection of delegates to get the Libyans to the negotiating table quickly and succeeded in doing so is undeniable.

The first few months showed the effectiveness of the new representative body (Crowley et al., 2021, pp. 5-6). On November 10 , the first meeting adopted a document on the national political program, which provided the basis for holding national elections on December 24, 2021, and for forming an interim government in December 2020. Even though the last step had to be postponed until January-February 2021, it is safe to say that the national elections will be held in December: Williams' team chose the most successful date falling on the 70th anniversary of the proclamation of independence 
by King Idris of Libya. The date is almost sacred for Libyans, and the step-by-step implementation of the devised plan, instead of attempts to hold elections "here and now," shows balanced realism and has won support for Williams' plans both among Libyans and in the international arena.

No less important is the demonstratively implemented principle of representation of different regions: it encourages representatives of warring factions (not only the NTC and the House of Representatives but also city-states and Fezzan tribes) to join efforts and reach a global consensus. Each of the external parties to the conflict will have an opportunity to lobby its positions through a particular person. Of course, such a delicate balance and relative transparency of the political processes is fraught with scandals, and in recent months there have been rumors of bribes and blackmail by some Libyan politicians who wanted to get in the lists of potential candidates for the interim government (Chuprygin, 2021). Nevertheless, this arrangement is probably optimal for achieving equal opportunities for domestic players and their foreign patrons.

It is noteworthy that although Stephanie Williams acted on behalf of the UN, her efforts to reconcile the parties to the conflict are considered by the world media and politicians as "American." The fears of further U.S. preponderance (after all, no one has described Ghassan Salame's activities as being earnestly "Libyan") in resolving the conflict prompted the world community to contain Williams' activism. In January 2021, UN Secretary-General Antonio Guterres appointed Slovak politician and diplomat Jan Kubis (a notable MGIMO graduate) to head UNSMIL (UNSMIL, 2021). For the United States, this final chord in Williams' active amateur performance seems unacceptable, and the media struggle to emphasize the role of American diplomacy in making a historical breakthrough continues.

Regardless of how the case ends, one can say that the image of the United States over the past six months has lost a touch of odium for Libyans. Of course, they criticized the list of participants in the Forum for Political Dialogue and the list of candidates for the interim government, which included many names hardly known in the country. 
However, there were no accusations of the U.S. for attempts to establish a pro-American government or disrupt the elections, apart from a few minor incidents.

This suggests that regardless of whether Stephanie Williams will be able to seriously influence the political process of building a new national structure (and, most likely, she will), the position of the United States in the Libyan conflict is very stable in the eyes of both opposing political camps. Further developments are likely to depend on whether the Joe Biden administration can ensure the last essential condition for the functioning of the elected interim government, namely the withdrawal of foreign military units from the Libyan territory (Belenkaya, 2020). This will require a substantial diplomatic effort on a global scale, a comprehensive approach to all the players involved in the confrontation, and will probably be more complex than the steps taken by Williams' team.

On the other hand, if Washington succeeds in implementing measures to ensure the withdrawal of foreign armed forces from the country, the United States' position in the Libyan arena will be indisputable. It is impossible to deny that Donald Trump's presidency brought Libya to a fundamentally new stage of American participation in the Middle Eastern affairs.

\section{PROSPECTS FOR MOSCOW}

The prospects for Russia's further involvement in the Libyan issue are vague. From the very beginning, Moscow's position of "equidistance" was temporary. Moscow seemed to be waiting for a clear winner to emerge. After the Kuznetsov aircraft carrier's call to the port of Tobruk and the famous video conference, the world media "married" the Kremlin and Haftar, creating a convincing legend that Russia supported the marshal in his political and military ambitions, joining the LNA fan club, which includes such respected actors as the UAE and Egypt.

Furthermore, Saudi Arabia and Israel clearly showed a tendency to support the man in uniform. However, throughout the subsequent period and up to the fall of 2019, Moscow continued to keep the position open for talks with everyone. By the end of 2019, there had 
developed a rather unexpected situation: Haftar, getting involved in a protracted and unpromising campaign to conquer Tripoli, put himself in the category of undesirable persons in high international offices. Suffice it to say that by launching an offensive on Tripoli, the marshal insulted the UN and its Secretary-General personally by thwarting a peace initiative launched under Guterres' personal patronage. That alone should have alerted LNA supporters. Moreover, for Russia, this behavior should have worked as a big stop sign but it did not. On the contrary, in the fall of 2019, when Haftar's offensive on Tripoli already choked, the world media began to report on the presence of Russian paramilitary organization Wagner at the forefront of Haftar's forces. Had Russia decided to finally make a choice? If so, the choice was unsuccessful since at the same moment Turkey openly entered the conflict on the side of the NTC and radically changed not only the military but also the political situation in Libya.

If we assume that the Kremlin is betting on Haftar, then the events of early 2020, when the marshal thwarted Russia's peace initiative, leaving Moscow without signing an agreement with al-Sarraj and repeating this debacle at the Berlin conference convened with Moscow's participation, should have been a wake-up call for Kremlin. But judging by subsequent events, Moscow's reaction was reserved. Either the Russian political leadership finally lost interest in Libya, leaving the settlement process in the hands of non-state actors, or Moscow's ultimate goal took a new form, as we will show below.

The Libyan issue is challenging to understand and more difficult to anticipate, although some things lie on the surface. As a result of Turkey's and Washington's activism, the balance of political forces in the country has become somewhat more transparent. While earlier we actively discussed which of the external players supported which forces, now we are talking about the final goals of these external players. What are they?

Judging by the actions performed, we can assume the following:

1. The United States seems committed to maintaining a unified Libyan state by any means necessary. All actions are aimed at creating a unitary government body. This will make it easier to 
control, and it is more convenient to counteract other external encroachments (Vernhes, 2021).

2. Turkey's main goal is to gain a foothold in the west of the country in Tripolitania. From here, it is convenient to influence the eastern Mediterranean, defending Turkey's right to offshore drilling and, in the future, to secure access to the yellow cake, which is said to be still somewhere in Libya (for details, see Tziarras, 2019, pp. 111-125). The issue of creating nuclear weapons has not been removed from the Turkish agenda. After all, everyone who is not lazy and who has money goes for this.

3. Russia is clearly trying to retain its influence in the east of the country even though Aguila Saleh is trying to jump ship, and Haftar will eventually leave for Virginia, USA. However, given the effort and resources already invested, Moscow may try to maintain its influence in the east of the country if only to retain a foothold for the future.

Thus, Turkey's and Russia's goals differ but not entirely, especially if an agreement is reached on the federalization of Libya. We may only guess whether this is what Abdel Hamid Dubaiba discussed with Haftar on the eve of the vote in Switzerland (Chuprygin, 2021).

4. Egypt, the United Arab Emirates, Italy, and France will not object to such a solution. The only obstacle to the federal project will be the United States. In this case, there is a possibility of coordinated action on the part of Turkey and Russia with the enthusiastic participation of several prominent local actors.

Given the formalistic resolutions of the Berlin II Conference on Libya and the political storm brewing in the aftermath of the latest LPDF meeting, which has been described by several experts as "disastrous," one has to conclude that the Libyan situation will hardly be resolved either this or next year. The persistent controversy over foreign interference and local disagreements indicates that the prospects for the war-torn country are still largely vague. 


\section{References}

Al-Marsad, 2020. Libya’s Civil Society Criticises UNSMIL’s Political Dialogue for Over-Representation of Islamists. Al-Marsad [online]. Available at: almarsad. co/en/2020/11/03/libyas-civil-society-criticises-unsmils-political-dialogue-forover-representation-of-islamists/ [Accessed 14 May 2021].

Belenkaya, M., 2020. In Libya’s War, Russia Is Directionless—and Falling Behind. The Moscow Times, 31 August [online]. Available at: www.themoscowtimes. com/2020/08/31/in-libyas-war-russia-is-directionless-and-fallingbehind-a71286 [Accessed 13 May 2021].

BBC, 2019. Khalifa Haftar: The Libyan general with big ambitions. $B B C$ [online]. Available at: www.bbc.com/news/world-africa-27492354 [Accessed 13 May 2021]. Blanchard, Ch. M., 2020. Libya: Conflict, Transition, and U.S. Policy. Congressional Research Service Report.

Breslauer, G. W., 1990. Soviet Strategy in the Middle East. Boston: Routledge.

Chuprygin A.V., 2021. Kak liviytsy pravitelstvo vybirali [How the Libyans Elected Their Government]. RSMD [online]. Available at: russiancouncil.ru/ analytics-and-comments/analytics/kak-liviytsy-pravitelstvo-vybirali/ [Accessed 12 May 2021].

Chuprygin, A.V., Chuprygina, L.A. and Matrosov, V., 2019. Key Actors in the Libyan Conflict (Friends and Foes of the Libyan Political Milieu). Russia in Global Affairs, 17(4), pp. 157-182.

Crowley, O., Dorda, M. and Moshashai, D., 2021. Inside Libya. Berlin: KAS.

Durrett, J. et al., 2019. U.S. Engagement in Libya: Diplomacy in a Protracted Conflict. Princeton.

EG24News, 2020. United Nations: The Arms Embargo to Libya Turned into a Joke. EG24News [online]. Available at: www.eg24.news/2020/02/united-nationsthe-arms-embargo-to-libya-turned-into-a-joke.html [Accessed 13 May 2021].

Mezran, K., and Varvelli, A., 2017. Foreign Actors in Libya's Crisis. Milano: ISPI, Atlantic Council.

Trenin, D., 2016. Russia in the Middle East. Moscow`s Objectives, Priorities, and Policy Drivers. Carnegie Endowment for International Peace, The Chicago Council on Global Affairs Paper [online]. Available at: carnegieendowment.org/ files/03-25-16_Trenin_Middle_East_Moscow_clean.pdf [Accessed 12 May 2021]. 
Tziarras, Z. (ed.), 2019. The New Geopolitics of the Eastern Mediterranean: Trilateral Partnerships and Regional Security. Oslo: PRIO.

Vernhes, S., 2021. US: What Is President Biden's Libya Strategy? The Africa Report [online]. Available at: www.theafricareport.com/68040/us-what-ispresident-bidens-libya-strategy/ [Accessed 12 May 2021].

UNSMIL, 2021. Ján Kubiš Takes Up Functions as the UN Secretary-General Special Envoy for Libya, Stresses UN Commitment to a Stable, Prosperous, Sovereign and Unified Libya. UNSMIL Official site. Available at: unsmil. unmissions.org/j\%C3\%A1n-kubi\%C5\%A 1-takes-functions-un-secretarygeneral-special-envoy-libya-stresses-un-commitment-stable [Accessed 14 May 2021]. 